Agro-Science Journal of Tropical Agriculture, Food, Environment and Extension Volume 11 Number 3 September 2012 pp 38 - 43

ISSN TI19-7455

\title{
APPRAISAL OF GRADUATE RESEARCH ON ARABLE CROPS IN THE UNIVERSITY OF NIGERIA, NSUKKA 2001-2010
}

\author{
Ikoro $^{1}$, D. E. Igbokwe ${ }^{2}$, E. M. Onyeonagu ${ }^{3}$, C. C. \& $\mathrm{Chah}^{3}$, J. M. \\ ${ }^{1}$ Department of Agricultural Extension, University of Nigeria, Nsukka \\ ${ }^{2}$ Department of Crop Science, University of Nigeria, Nsukka
}

\begin{abstract}
The study appraised graduate research on arable crops in the University of Nigeria, Nsukka from 2001to 2010. Data were collected through content analysis from 32 graduate researsch works, while percentages were used for presenting the data. The results show that $59.58 \%$ of those who enrolled for post graduate programme from 2001 to 2010 were master of science $(\mathrm{M} . \mathrm{Sc})$, while $40.62 \%$ were doctors of phillsophy (Ph.Ds). A greater percentage of the graduates who offered agronomy (63.63\%), plant breeding and genetics (66.66\%), and plant pathology (60\%), were M.Scs. Fifty percent each of those that offered weed science and forage were M.Scs and Ph.Ds. However, the only graduate student that offered nematology was a Ph.D graduate. On area of specialization, $34.37 \%$ offered agronomy, $28.12 \%$ plant breeding and $15.62 \%$, plant pathology. The least enrollment came from nematology (3.12\%), weed science, entomology and forage crops (6.25\%) each.There is the need to encourage graduates to pursure their careers in areas of nematology, entomology and forage crop production.
\end{abstract}

Keywords: Graduate research, arable crop, areas of specializion

\section{INTRODUCTION}

Majority of Nigeria's rural poor depend on agriculture for their livelihood. Agriculture employs over 70 percent of the active labour force (World Bank, 2000; Olaolu 2010; Agada, 2011). The sector has been identified by the federal government of Nigeria (FGN) as the key development priority in its desire to eradicate extreme poverty and hunger by 2015 through diversifying the economy away from the oil sector. The effort to achieve this cannot be realized if agricultural research is neglected. World Bank (2004) posits that growth in agricultural productivity depends on the application of science technology and information provided through agricultural research and development (R\&D).

Universities as arms of the National Agricultural Research System (NARS) are made up of universities of agriculture that are specialized in agro- based courses and the general universities that have faculties of agriculture. They are seen as having the capabilities of knowledge and human development because of their involvement in the education and training of future staff for other institutions in the system and provide intellectual leadership in the development process of the nations. It is noted that as universities participate actively in research and technology transfer activities, they develop knowledge, experience and technology which are relevant to local conditions not only for their use in the education and training process, but also their application by the respective agencies. In the long run, the cumulative experience will have substantial beneficial impact on the NARS (FAO, 1993).

Sabo (2005), posits that the main criteria for ranking "world class universities" are not so much the volume of teaching, students population, or community service, but research output. According to Cetto (1998) one index for measuring research output is the number and quality of published works by Nigerian international journals, and by the world distribution of active serial titles, coming from the universities, which contribute to the generation, dissemination and application of scientific knowledge for development in Nigeria and other countries. Similarly, Chiemeke et al (2009) recommended that research output and findings from the tertiary institutions must have an impact on the end users. Rivera et al (2009) reported a positive and significant relationship between commercial linkages and research productivity. 
This work becomes necessary because there have been debates over the impacts of universities' on the surrounding rural communities who use agriculture as their major source of livelihood. Besides, considering the outputs in terms of graduates produced in different levels and specialization, research on arable crop will be of immense benefit since arable crops form the major staple of Nigerians. In addition, using graduate research works is important since findings at this level are expected to make appreciable impacts on the agricultural activities of the farmers. This research sought to answer the following questions: what are the different levels of graduates produced from the Department of Crop Science in the University of Nigeria Nsukka? What are their areas of specializations? And how relevant are their research findings at farm level?

\section{MATERIALS AND METHOD}

Graduate research used in this work are those projects carried out by students of Department of Crop Science, Faculty of Agriculture, University of Nigeria, Nsukka for the award of master of science (M.Sc) and doctor of philosophy (Ph.D) degrees in all the fields related to arable crop production. These include agronomy, plant breeding and genetics, plant pathology, entomology, forage crop production, and weed science and nematology. The work considered the year of publication, level and areas of specialization of each of the graduates involved. The Faculty of Agriculture University of Nigeria, Nsukka (UNN) has the following departments: Crop Science, Animal Science, Agricultural Economics, Agricultural Extension, Home Science, Nutrition and Dietetics and Food Science and Technology. Out of these, Department of Crop Science was purposively selected being responsible for producing graduates on arable crops which is the major aspect of agricultural activities of the farming communities around Nsukka. Nineteen M.Sc. and thirteen Ph.D dissertations and theses respectively, were used.

To determine the level of graduates who studied arable crop science, all the graduate research works from the Department of Crop Science were read from the University and faculty libraries and the data on the different levels were drawn. The process entailed content analysis, making summaries and drawing out relevant results.The variables were measured by arranging the graduate works from the studied department serially, into title, year of publication and degrees of post graduate study (M.Sc or $\mathrm{Ph} . \mathrm{D})$. Percentages were used to summarize the data collected.

\section{RESULTS AND DISCUSSION}

Categories of graduate research on arable crops in the University of Nigeria, Nsukka, based on degrees

A total of 32 students enrolled for both M.Sc and $\mathrm{Ph} . \mathrm{D}$ degree levels during the period. Table 1 shows that nineteen $(59.4 \%)$ of these were for M.Sc and thirteen (40.6\%) for Ph.D., Majority $(63.63 \%)$ of those who offered agronomy were for M.Sc, whereas only a few $36.36 \%$ were Ph.Ds. All (100\%) of those that offered nematology from 2001-2010 were M.Sc. Also, $66.66 \%$ and $60 \%$ of those who offered plant breeding and plant pathology, respectively, were for M.Sc. While only one Ph.D candidate specialized in entomology. Fifty percent each of those that graduated from forage crops were M.Scs and Ph.Ds, respectively. The result is an indication that from 2001 to 2010, the Department of Crop Science of the University of Nigeria, Nsukka produced more M.Scs than Ph.Ds.

Categories of graduate research on arable crops in the UNN 2001-2010 based on specialization Data in Table 2 show the distribution of graduate research based on specialization. The study revealed that out of the 32 graduates who enrolled for the seven different areas of specializations considered, $34.4 \%$ offered agronomy, $28.1 \%$ plant breeding and genetics, $15.6 \%$ plant pathology. Only a few (3.1\%) enrolled in nematology.

The implication of the results is that more students graduated in agronomy and plant breeding and genetics than other areas of specialization. This is a kind of setback to agricultural development because without these other neglected fields, agricultural development will not make any head way. 
Table 1: Categories of graduate research based on degrees of postgraduate studies and area of specialization, UNN, 2001-2010

\begin{tabular}{llllll}
\hline & & \multicolumn{2}{c}{ Ph.D. $(\mathbf{n = 1 3})$} & \multicolumn{2}{c}{ M.Sc. $(\mathbf{n = 1 9})$} \\
Variable & Total $(\mathbf{n = 3 2})$ & Frequency & Percentage & Frequency & Percentage \\
\hline Agronomy & 11 & 4 & 36.36 & 7 & 63.63 \\
Plant Breeding & 9 & 3 & 33.33 & 6 & 66.66 \\
Plant Pathology & 5 & 2 & 40.00 & 3 & 60.00 \\
Weed Science & 2 & 1 & 50.00 & 1 & 50.00 \\
Nematology & 1 & - & 0.00 & 1 & 100.00 \\
Entomology & 2 & 2 & 100.00 & - & 0.00 \\
Forage Crop & 2 & 1 & 50.00 & 1 & 50.00 \\
Total & 32 & 13 & 40.62 & 19 & 59.38 \\
\hline
\end{tabular}

Table 2: Categories of graduate research based on area of specialization, UNN, 2001-2010

\begin{tabular}{|c|c|c|c|c|}
\hline \multirow[b]{2}{*}{ Variable } & \multicolumn{2}{|c|}{ Ph.D. $(n=13)$} & \multicolumn{2}{|c|}{ M.Sc. $(n=19)$} \\
\hline & Frequency & Percentage & Frequency & Percentage \\
\hline Agronomy & 4 & 30.76 & 7 & 36.84 \\
\hline Plant Breeding & 3 & 23.07 & 6 & 31.57 \\
\hline Plant Pathology & 2 & 15.58 & 3 & 15.78 \\
\hline Weed Science & 1 & 7.69 & 1 & 5.26 \\
\hline Nematology & - & - & 1 & 5.26 \\
\hline Entomology & 2 & 15.38 & - & - \\
\hline Forage Crop & 1 & 7.69 & 1 & 5.26 \\
\hline Total & 13 & 100 & 19 & 100 \\
\hline
\end{tabular}

Table 3: Isolation of $\mathrm{Ph} . \mathrm{D}$ graduate research relevant at farm level

\begin{tabular}{cccccc}
\hline S/N & Specialization & Year & TF & FR & $\begin{array}{c}\text { \% of } \\
\text { research }\end{array}$ \\
\hline 1 & Crop production & 2008 & 40 & 35 & $87.75^{* *}$ \\
2 & $\checkmark$ & 2005 & 162 & 127 & $78.39^{* *}$ \\
& & & 202 & 158 & $78.21^{* *}$ \\
1 & Plant breeding & 2009 & 40 & 10 & 25.00 \\
2 & $\checkmark$ & 2006 & 32 & 15 & 46.87 \\
3 & $\checkmark$ & 2005 & 35 & 12 & 34.28 \\
& & & 107 & 37 & 34.57 \\
1 & & 2006 & 24 & 19 & $70.37^{* *}$ \\
2 & Plant pathology & 2004 & 39 & 24 & $61.53^{*}$ \\
& $\checkmark$ & 2005 & 63 & 43 & $68.25^{*}$ \\
& & 2010 & 30 & 25 & $83.33^{* *}$ \\
2 & Weed science & 2005 & 52 & 40 & $86.53^{* *}$ \\
& Forage & 2004 & 28 & 24 & $85.71^{* *}$ \\
& Entomology & $\checkmark$ & 42 & 33 & $78.57^{* *}$ \\
\hline
\end{tabular}

Note: $\mathrm{TE}=$ Total research findings.

$\mathrm{FR}=$ Findings relevant at farm relevant

- $=$ very relevant 
Appraisal of Graduate Research on Arable Crops in The University of Nigeria, Nsukka

Table 4: Isolation of M.Sc graduate research findings relevant at farm level

\begin{tabular}{cccccc}
\hline S/N & Specialization & Year & TF & FR & $\begin{array}{c}\text { \% of research finding, } \\
\text { relevant at farm level }\end{array}$ \\
\hline 1 & Crop production & 2010 & 13 & 11 & $84.61^{* *}$ \\
2 & $\checkmark$ & 2008 & 13 & 9 & $69.23^{*}$ \\
3 & $\checkmark$ & 2005 & 36 & 30 & $83.33^{* *}$ \\
4 & $\checkmark$ & 2004 & 20 & 14 & $70.00^{* *}$ \\
5 & $\checkmark$ & 2002 & 19 & 12 & $63.15^{*}$ \\
6 & $\checkmark$ & 2001 & 49 & 30 & $73.17^{* *}$ \\
& & 150 & 106 & $70.66^{* *}$ \\
1 & Sub total & 2010 & 38 & 12 & 31.57 \\
2 & Plant breeding & 2010 & 12 & 6 & 50.00 \\
3 & $\checkmark$ & 2005 & 30 & 5 & 16.66 \\
4 & $\checkmark$ & 2002 & 71 & 22 & 30.98 \\
& & 151 & 45 & 29.80 \\
1 & Sub total & 2007 & 34 & 21 & $61.76^{*}$ \\
2 & Plant pathology & 2005 & 114 & 81 & $71.05^{* *}$ \\
& Sub total & & 148 & 102 & $70.34^{* *}$ \\
& Weed science & 2004 & 14 & 10 & $71.42^{* *}$ \\
& Nematology & 2004 & 27 & 18 & $66.66^{*}$ \\
& Forage & 2005 & 35 & 27 & $77.14^{* * *}$ \\
\hline
\end{tabular}

Note: $\mathrm{TE}=$ Total research findings.

$\mathrm{FR}=$ Findings relevant at farm relevant

- $=$ very relevant

Isolation of Ph.D graduate research on arable crops relevant at farm level in the UNN, 20012010

Table 3 showed that the most relevant $\mathrm{Ph} . \mathrm{D}$ graduate research at farm level was that of 2008 crop production $(87.8 \%)$. This was closely followed by forage of $2010(86.5 \%)$. Others were of entomology of $2005(85.7 \%)$, weed science of $2005(83.3 \%)$, entomology of 2004 crop production of $2005(78.4 \%)$ and plant pathology of $2006(70.4 \%)$.Plant pathology of $2004(61.5 \%)$ was just relevant.

In a nutshell, about $69.3 \%$ of Ph.D research findings in the period considered was very relevant at farm level, $7.7 \%$ was just relevant, while $23 \%$ was not relevant at farm level. This makes for agricultural development because the more relevant technologies are at farm level the more the farmers are likely to adopt them for agricultural production.

The general appraisal of the research results/findings of graduate works both at M.Sc. and $\mathrm{Ph} . \mathrm{D}$ degrees clearly indicated that the graduates came out with good results that are relevant at farm level. These findings are of great improvement compared to the result of William, Rae and Vernon (1998) who appraised the three universities in Nigeria including University of Nigeria (UNN) and posited that UNN has not made impact at the farm level. According to them, only Ahmadu Bello University was able to produce significant research results that are locally relevant for the benefits of the communities around. 
Table 5: Titles, year of publication, areas of specializations and levels of graduate research at UNN from 2001-2010

\begin{tabular}{|c|c|c|c|c|}
\hline $\mathrm{S} / \mathrm{N}$ & Title & Year & Specialization & Level M.ScPh.D \\
\hline 1 & $\begin{array}{l}\text { Studies of fertilizer nitrogen and cutting management of sown grass and } \\
\text { legume pasture in pure and mixed swards }\end{array}$ & 2010 & Forage crop production & $\sqrt{ }$ \\
\hline 2 & Juvenile morphological markers for maleness in fluted pumpkin $s$ hook f) & 2010 & Plant breeding and genetics & $\sqrt{ }$ \\
\hline 3. & $\begin{array}{l}\text { Assessment of morphological, nutritional and cytological characteristics of } \\
\text { some Nigerian cucurbita species }\end{array}$ & 2010 & $\begin{array}{l}\text { Plant Breeding and } \\
\text { Genetic }\end{array}$ & $J$ \\
\hline 4. & $\begin{array}{l}\text { Evaluation of growth, yield and post-harvest qualities of twelve cassava } \\
\text { (Manihotes culentacrantz) genotypes in Nsukka Nigeria. }\end{array}$ & 2010 & Agronomy & $\sqrt{ }$ \\
\hline 5. & $\begin{array}{l}\text { Morphological and genetic studies of ten cultivars of Capsicumannum in } \\
\text { relation to quality traits and yield. }\end{array}$ & 2009 & $\begin{array}{l}\text { Plant breeding and } \\
\text { genetics }\end{array}$ & $J$ \\
\hline 6. & $\begin{array}{l}\text { Time of planting responses model and yield stability of selected improved } \\
\text { upland rice lines in the Southern Guinea Savanna of Nigeria }\end{array}$ & 2008 & Agronomy & $\sqrt{ }$ \\
\hline 7. & $\begin{array}{l}\text { Effects of plant spacing and organic manure rates on yield and nutrient } \\
\text { composition of waterleaf (Talinumtriangulare) }\end{array}$ & 2008 & Agronomy & $J$ \\
\hline 9. & $\begin{array}{l}\text { Prophylactic effect of paw-paw leaf and bitter leaf extracts on foliar myco- } \\
\text { pathogens of groundnut (Arachis hypogea. 1.) }\end{array}$ & 2007 & Plant pathology & $J$ \\
\hline 10. & Diallel analysis of twelve varieties of maize (Zea mays 1$)$ & 2006 & $\begin{array}{l}\text { Plant Breeding and } \\
\text { Genetics }\end{array}$ & $J$ \\
\hline 11. & $\begin{array}{l}\text { Studies of variability in Phytophthorainfestans, causal agent of late blight of } \\
\text { potato, and strategy of control in the western highilands of Cameroon }\end{array}$ & 2006 & Plant pathology & $J$ \\
\hline 12. & $\begin{array}{l}\text { Studies on the suitability of some improved cassava genotypes for } \\
\text { intercropping in cassava-based. }\end{array}$ & 2005 & Weed science & $\sqrt{ }$ \\
\hline 13. & $\begin{array}{l}\text { Studies on management of Strigahermonthica (del.); benth in maize with } \\
\text { intercrops trap crop varieties and nitrogen fertilization in Benue State, } \\
\text { Nigeria }\end{array}$ & 2005 & Weed science & $J$ \\
\hline 14. & $\begin{array}{l}\text { Studies on control of cowpea Bruchidcallosobruchus materials and varietal } \\
\text { resistance. }\end{array}$ & 2005 & Entomology & $J$ \\
\hline 15. & $\begin{array}{l}\text { The effects of some aspects of field management and post-harvest agro- } \\
\text { botanical treatments on yam (Dioscosrearotundata) }\end{array}$ & 2005 & Agronomy & $J$ \\
\hline 16 & $\begin{array}{l}\text { Inheritance of some agronomic and yield characters in egusi melon } \\
\text { (Colocynthiscitrullus } 1 .)\end{array}$ & 2005 & $\begin{array}{l}\text { Plant Breeding and } \\
\text { Genetic }\end{array}$ & $J$ \\
\hline 17. & $\begin{array}{l}\text { Studies on the post-harvest storage of some leafy and fruit vegetables in } \\
\text { "vegetable basket" and associated pathogens }\end{array}$ & 2005 & Plant pathology & $J$ \\
\hline 18. & $\begin{array}{l}\text { Evaluation of neem seed extract, benlate, and apron plus sods as seed } \\
\text { treatment for the control of some fungal diseases in eggplant } \\
\text { (Solanummelogena } 1 \text { ). }\end{array}$ & 2005 & Plant pathology & $J$ \\
\hline 19 & $\begin{array}{l}\text { Screening of indigenous pepp one Ph.D candidate specialized in entomology } \\
\text { er genotypes for resistance to natural occuringing pepper veinal mottle virus }\end{array}$ & 2005 & $\begin{array}{l}\text { Plant Breeding and } \\
\text { Genetics }\end{array}$ & $J$ \\
\hline 20 & Reclamation of a run-down pasture through improved management & 2005 & $\begin{array}{l}\text { Forage crop } \\
\text { production }\end{array}$ & $J$ \\
\hline . & $\begin{array}{l}\text { Evaluation of cultivars of sweet potato (Ipomeabatata l. lam) and soybean } \\
\text { (Glycine max (1.) merrill) grown in intercropping systems. }\end{array}$ & 2005 & Agronomy & $J$ \\
\hline 21. & $\begin{array}{l}\text { Evaluation of varietal response of soybean (Glycinemax (1.) merrill) and its } \\
\text { intercrop to bean pod mottle virus disease in Nsukka plain of southeastern } \\
\text { igeria. }\end{array}$ & 2004 & Plant pathology & $J$ \\
\hline 22. & $\begin{array}{l}\text { Studies on fertilizer treatment and cutting management of fluted pumpkin } \\
\text { (Telfairiaoccidentalis hook f.) agronomy. }\end{array}$ & 2004 & Vegetable crops. & $J$ \\
\hline 23. & $\begin{array}{l}\text { Infectivity of meloidogne and m. javanica (treub) chitwood on elite and local } \\
\text { cultivars of tomato in the humid tropics. }\end{array}$ & 2004 & $\begin{array}{l}\text { Nematology } \\
\text { (protection) }\end{array}$ & $J$ \\
\hline 24. & $\begin{array}{l}\text { Effects of variety and seed size on the response of soybean (Glycinemax (1) } \\
\text { merrill) to commercial formulated herbicide mixture } \\
\text { (metolachlor+metobromuron) }\end{array}$ & 2004 & Weed science & $J$ \\
\hline 25. & $\begin{array}{l}\text { Effects of soybean and maize spatial arrangement and planting density in } \\
\text { disease mixture on insect pest, weed and disease damage of the soybean and } \\
\text { maize components. }\end{array}$ & 2004 & Entomology & $J$ \\
\hline 26. & $\begin{array}{l}\text { Studies on growth, yield, organic matter turn-over and soil nutrient changes } \\
\text { in cassava (Manihotesulentacrantz)/vegetable cowpea (Vignaunguiculata } 1 . \\
\text { walp.) mixures. }\end{array}$ & 2002 & Agronomy & $J$ \\
\hline 27. & $\begin{array}{l}\text { Study of agronomic characteristics of twelve advanced breeding lines of } \\
\text { upland rice in Nsukka agro-ecology. }\end{array}$ & 2002 & Agronomy & $J$ \\
\hline 28. & $\begin{array}{l}\text { Effects of nitrogen fertilization and legume nitrogen contribution on growth } \\
\text { and yield of cassava (Manihotesculentagrantz) and soybean (Glycinemax (1) } \\
\text { merrill) intercrops. }\end{array}$ & 2002 & Agronomy & $J$ \\
\hline 29. & $\begin{array}{l}\text { Genetic relationships and inheritance pattern of agronomic characters in } \\
\text { interspecific crosses of tomatoes (Lycopersiconspp) }\end{array}$ & 2002 & Plant breeding and genetics & $J$ \\
\hline 30. & $\begin{array}{l}\text { Evaluation of twelve (12) upland rice (Oryzae sativa. 1.) genotypes for high } \\
\text { yield and blast (Pyrculariaoryzae) infection under Nsukka condition. }\end{array}$ & 2002 & Plant breeding and genetics & $J$ \\
\hline 31. & $\begin{array}{l}\text { Effects of planning dates, rates of carbofuran and cultivar of sorghum at } \\
\text { Nsukka }\end{array}$ & 2001 & Agronomy & $J$ \\
\hline 32. & $\begin{array}{l}\text { Agro-botanical studies and responses of Mucunaflagellipes (voger ex hook) } \\
\text { to lime and phosphorous fertilizer treatments in field culture. }\end{array}$ & 2002 & $\begin{array}{l}\text { Agronomy } \\
\text { Productions }\end{array}$ & 13 \\
\hline
\end{tabular}


Isolation of M.Sc graduate research on arable crops relevant at farm level at $\mathrm{UNN}$, 20012010

The MSc graduate works that are very relevant at farm level are the following in descending order: crop production of 2010 (84.6\%), $2005(83.3 \%), 2001(73.2 \%)$, plant pathology $2005(71.1 \%)$ and crop production $2004(70 \%)$. The ones that are just relevant include: crop production of 2008 (69.2\%), 2002 (63.6\%), plant pathology $(61.8 \%)$ and plant breeding of $2010(50 \%)$. This result will also makes for agricultural development.

Graduate research on arable crops at UNN based on years of publication from 2001-2010

The results showed that more $(28.1 \%)$ of the graduate research works appraised were from the year 2005. The next was 2002 (18.8\%), 2004 (15.6\%), 2010 (11.8\%), 2008 and 2006 $(6.3 \%)$, respectively. The least was from the years 2009 and 2007 (3.1\%) each. The implication of the result is that graduate enrollment in the UNN in 2005 must have made better contributions to agricultural development more than the other years. This conclusion is reached based on the fact that the general findings showed relevant results that could be adopted by poor resource farmers at the farm level, which in effects makes for more agricultural production and development

\section{CONCLUSION}

The result showed that the Department of Crop Science of the University of Nigeria produced more M,Sc than Ph.Ds graduates and majority of the graduates specialized in agronomy, plant breeding and genetics from 2001 to 2010 . While the area of plant pathology followed closely. The least area of specialization were students graduated from was nematology and closely related to this are weed science, entomology and forage crop production. Greater percentages of graduate research findings were relevant at the farm level.Based on the findings, it was recommended that students be encouraged to offer these areas of specializations where students were lacking because they are needed for agriculture development and food security for both rural communities around UNN and Nigeria as a whole. More so, these relevant findings at farm level should be disseminated to the farmers in the language they will understand for upward adoption.

\section{REFERENCES}

Agada, M.O. (2011). Socio-economic and cultural analysis of food security situation among selected ethnic groups in North Central Nigeria. A Ph.D Thesis submitted to the Department of Agricultural Extension, University of Nigeria, Nsukka.

Cetto, A. (1998). Scientific journal publishing in the developing world.Lesotto Coasted, Chennas, India.

Chiemeke, S., Longe, O.B. Longe, F.A.andShaib, I.O. (2009)Research outputs from Nigerian tertiary institutions: An empirical appraisal.Library philosophy and practice. ISSN 1522-0222

Ephraim, E.O. (2004). Research and technological development in Nigeria.Available in http://less man.ac.uk/prest/SCOPE/.

Food and Agricultural Organization (FAO) (1993).The role of Universities in national agricultural resources.World Food Summit, November 13-17, 1993, Rome. Pp.5-10.

Olaolu, M.O. (2010). Impact of national FADAMA Development Project Phase (11) on poverty reduction and food security among rice farmers in Kogi State.An M.Sc. Research findingsDepartment of Agricultural Extension, University of Nigeria Nsukka.

Rivera, R; Sampedro, J.L; Dutrent,G; Ekboir, J.M. and Vera-Cruz, J.A.O. (2009). Do linkages between commercial farmers and academic researchers influence research productivity? The Mexican case.Available http://hdl.handle.net/1853/34997.

Sabo, B. (2005). Universities, research and development in Nigeria: Time for a paradigm shift. Paper forllth General Assembly on Rethinking African Development. Beyond impasses: Towards alternavtives, Maputo, Mozambique. Available: http:11/papers/bako.pdf. 